KYIV-MOHYLA

LAW \& POlitics JOURNAL

KYIV-MOHYLA SCHOLARLY PEER-REVIEWED JOURNALS

The Influence of Public Corruption and Human Values on Trust in the Police: A European CrossNational Perspective

Author(s): Sabrina Pfister

Source: Kyiv-Mohyla Law and Politics Journal 5 (2019): 119-140

Published by: National University of Kyiv-Mohyla Academy

http://kmlpj.ukma.edu.ua/ 


\title{
The Influence of Public Corruption and Human Values on Trust in the Police: A European Cross-National Perspective.
}

\author{
Sabrina Pfister \\ Institute of Sociology \\ University of Zurich, Switzerland
}

\begin{abstract}
Police forces are an important part of every democratic system and depend on societal legitimacy to perform their duties. Societal legitimacy stems from compliance with binding principles, like human rights and national law, and from broad acceptance from the people. Accordingly, police forces need the public's trust to perform their duties in today's European democracies. This paper investigates trust in police forces based on individual and contextual factors found in European countries. To explain trust in police forces, this paper uses human values on an individual level as well as perceived public-sector corruptionon a macro level. The analysis is based on data from the European Social Survey 2016 (ESS) and the Corruption Perception Index 2015 (CPI). It combines individual and contextual factors using multilevel models to explore differing levels of trust in police forces as well as the dynamics between perceived public-sector corruption, human values, and trust in the police. The results confirm previous findings that trust in police forces erodes in the face of perceived public-sector corruption, while human values play a sub-ordered role in the explanation of trust in the police in European countries.
\end{abstract}

Key Words: Trust in the Police, CPI, Human Values, ESS, Multilevel analysis

\section{Introduction}

In Greece, the level of trust in the police dropped dramatically between 2002 and 2011. ' Such a decline prompts a question: how can trust in police be explained? Public institutions need to be trusted to function effectively. ${ }^{2}$ For state institutions to fulfill their tasks, they need a certain amount of operational space. But this space can be maintained long-term only if citizens trust theirstate's institutions. ${ }^{3}$ When citizens trust

$1 \quad$ Heikki Ervasti, Antti Kouvo, and Takis Venetoklis, "Social and Institutional Trust in Times of Crisis: Greece, 2002-2011," Social Indicators Research 141, no. 3 (2019).

2 William A. Gamson, Power and discontent (Homewood Ill.: Dorsey Press, 1968).

3 Benjamin Höhne, Vertrauen oder Misstrauen? Wie stehen die Ostdeutschen 15 Jahre nach der Wiedervereinigung zu ihrem politischen System? (Marburg: Tectum, 20o6), http://deposit.dnb. 
their state's institutions, they legitimate them. ${ }^{4}$ Thus, institutional legitimacy depends on citizen trust.

Differences in citizen trust levels can be explained by differences in institutional corruption among states. Interest in corruption has increased notably in recent years, both among social scientists and the public. For example, in 2015 a leak of over 11 million financial documents known as the 'Panama papers' had an impact in Europe. 5 Though offshore business is legal, the Panama papers revealed that some shell corporations were being used for illegal purposes, such as fraud or tax evasion. ${ }^{6}$ Some former and current European leaders were involved. The former Prime Minister of Iceland, for example, had links to anonymous offshore companies. ${ }^{7}$ Russian President Vladimir Putinhad links to hidden money. ${ }^{8}$ While instances of real or perceived corruption like those revealed in the Panama papers have gained considerable international attention, corruption is widespread and affects the lives of many people in many societies. ${ }^{9}$ And when corruption is systematically present in one part of society, it has a lasting impact across thatsociety. ${ }^{10}$

While real and perceived public-sector corruptionaffects trust in public institutions and the policeon a macro-level,"'human values can explain people'strust in public

de/cgi-bin/dokserv?id=2774541\&prov=M\&dok_var=1\&dok_ext=htm.

4 Arthur Benz, "Vertrauensbildung in Mehrebenensystemen," in Politisches Vertrauen: Soziale Grundlagen reflexiver Kooperation, ed. Rainer Schmalz-Bruns and Reinhard Zintl, Schriftenreihe der Sektion Politische Theorien und Ideengeschichte in der Deutschen Vereinigung für Politische Wissenschaft 2 (Baden-Baden: Nomos, 2002).

The International Consortium of Investigate Journalists, "Giant Leak of Offshore Financial Records Exposes Global Array of Crime and Corruption," accessed October 31, 2019, https:// www.webcitation.org/6gVXG3LvI?url=https://www.occrp.org/en/panamapapers/overview/ intro/.

6 Ariès Quentin, "EU vows to act quickly on Panama Papers," accessed October 31, 2019, https:// en.wikipedia.org/wiki/Panama_Papers_(Europe).

7 Frederik Obermaier and Bastian Obermayer, "A storm is coming: Panama papers," accessed October 31, 2019, https://panamapapers.sueddeutsche.de/articles/56fecocdarbb8d3c3495adfc/.

8 Frederik Obermaier and Bastian Obermayer, "Die Panama Papers in aller Welt: Russland," accessed October 31, 2019, https://panamapapers.sueddeutsche.de/ articles/56fecocdaibb8d3c3495adfc/.

9 Werner Plumpe, "Korruption: Annäherungen an ein historisches und gesellschaftliches Phänomen," in Geld — Geschenke-Politik: Korruption im neuzeitlichen Europa, ed. Jens I. Engels, Andreas Fahrmeir and Alexander Nützenadel, Historische Zeitschrift Beihefte N. F., 48 (München: Oldenbourg, 2009).

10 Bo Rothstein, "Anti-corruption: The indirect 'big bang' approach," Review of International Political Economy 18, no. 2 (2011).

11 JuhaKääriäinen, “Trust in the Police in 16 European Countries: A Multilevel Analysis," European Journal of Criminology 4, no. 4 (2007). 
institutions and the police on a micro-level.12 Strikingly, though various factors have been used to explain trust in the police, hardly any study has investigated the influence of human values. Schwartz defines 'values' "as desirable transsituational goals, varying in importance, that serve as guiding principles in the life of a person or other social entity." Each value has consequencesthat may be compatible or in conflict with other values. Schwartz's theory focuses onthe following 10 values: universalism, benevolence, tradition, conformity, security, power, achievement, hedonism, stimulation, and selfdirection. ${ }^{13}$

The police can support or undermine values through their actions or inaction. Therefore, the differences in the importance amongthese values across a society's population can be assumed to establish different levels of trust in the police within that society. Human values, therefore, play an important role in understanding differences in trust in the police. ${ }^{14}$

Since both perceived public-sector corruptionand human values influence trust in the police, this paper studies their separateand combined effect on trust in the police. It begins by explaining the theoretical conceptsbehind trust in the police, perceived public-sector corruption, and human values. This explanation is followed by a description of the data and the statistical methods for the empirical analysis. Then, analysis's descriptive and bivariate results are presented, followed by the results of the multilevel analysis of the 23 European countries and a discussion of them. Finally, this paper draws various conclusions and identifies where more research is needed.

\section{Theoretical considerations}

\section{Trust in the Police}

Trust is a complex social phenomenon. ${ }^{15}$ For example, trustcan exist between individuals, between a person and an institution, andbetween institutions. ${ }^{16}$ This paper focuses on trust in the police as an institution.

Davide Morselli, Dario Spini, and Thierry Devos, “Trust in institutions and human values in the European context: A comparison between the World Value Survey and the European Social Survey," Psicologiasociale 10, no. 3 (2015).

13 Shalom H. Schwartz, "Are There Universal Aspects in the Structure and Contents of Human Values?," Journal of Social Issues 50, no. 4 (1994).

14 Sabrina Pfister, "Vertrauen in die Polizei: Schweiz - Europa - Welt" (Dissertation, Universität Zürich, 2020-forthcoming).

15 Henning Nuissl, "Bausteine des Vertrauens: Eine Begriffsanalyse," Berliner Journal für Soziologie 12, no. 1 (2002).

16 Andrea Maria Dederichs, "Vertrauen als affektive Handlungsdimension: Ein emotionssoziologischer Bericht," in Interpersonales Vertrauen: Theorien und empirische Befunde, ed. Martin K. W. Schweer (Wiesbaden: VS Verlag für Sozialwissenschaften, 1997). 
Institutional trust refers to the complex structure of an institution as a whole and not to the individuals within the institution. It focuses on the institution's functioning and serves to reduce the complexity of managing an institution. ${ }^{17}$ Institutions fulfill a necessary and important role in our complex world. Institutions provide"stable, valued, recurring patterns of behavior." 18 Trust is an important factor for managing and reducing complexity. ${ }^{19}$

The police are part of the political system and therefore can be regarded as a representative of the government. ${ }^{20}$ Trust in the police, however, is a special case of trust in state institutions. The police's legitimacy dependson whether the public accepts the police. The police need the trust of the population to properly perform their duty, especially in democracies like Europe's democracies. ${ }^{21}$ Public attitudes towards the police are influenced by the police's structure and operations; all facets of the police function matter. ${ }^{22}$

\section{Perceived Public-Sector Corruption}

In this paper, "corruption is the abuse of entrusted power for private gain." 23 "It is understood to mean either offering and accepting money, gifts, or other benefits. The aim is to commit someone in the business world to a breach of duty or a breach of trust." 24

Research on corruption has found that corruption has negative consequences. ${ }^{25}$ In public services, corruption means that goods and services are not distributed fairly

17 Höhne, Vertrauen.

18 Samuel P. Huntington, "Political Development and Political Decay," World Politics 17, no. 03 (1965): 394 .

19 Niklas Luhmann, Vertrauen: Ein Mechanismus der Reduktion sozialer Komplexität, 4. th ed., UTB 2185 (Stuttgart: Lucius \& Lucius, 2000 [1968]).

20 Kääriäinen, "Trust Police.”

21 Kenneth Newton and Pippa Norris, "Confidence in public institutions: Faith, culture or performance?," in Disaffected democracies: What's troubling the trilateral countries?, ed. Susan J. Pharr and Robert D. Putnam (Princeton, NJ: Princeton University Press, 200o); Tom R. Tyler, "Trust and legitimacy: Policing in the USA and Europe," European Journal of Criminology 8, no. 4 (2011).

22 David Easton, A systems analysis of political life (New York: Wiley, 1965).

23 Transparency International, "What is Corruption?," accessed June 19, 2018, https://www. transparency.org/\%2owhat-is-corruption\#define.

24 Transparency International Schweiz, “Geschäftsgrundsätze für die Bekämpfung von Korruption, Ausgabe für kleine und mittlere Unternehmen (KMU)” (Bern, 2008), 7.

25 For an overviews of reseachs on conequences of corruption see: Ulrich von Alemann, "Politische Korruption: Ein Wegweiser zum Stand der Forschung," in Dimension politischer Korruption: Beiträge zum Stand der internationalen Forschung, ed. Ulrich von Alemann, Politische Vierteljahresschrift Sonderhefte (Wiesbaden: VS Verlag für Sozialwissenschaften, 2005), 38-40. 
among the people. ${ }^{26}$ Corruption also undermines political processes. ${ }^{27}$ Corruption is a threat to a good government ${ }^{28}$; it diminishes the quality of state-providedservices. ${ }^{29}$ Furthermore, corruption reduces trust in state institutions. ${ }^{30}$ This loss of trust in turn leads to a delegitimization of the political system. ${ }^{31}$ And corruption violates fundamental democratic principles because it can lead to systematic manipulation of political institutions and laws. ${ }^{32}$

The police are responsible for enforcing formalized norms impartially. ${ }^{33}$ Many studies show that generalized trust or trust ininstitutions increaseswhen all persons are treated fairly and equally. ${ }^{34}$ Corruption, on the other hand, violates impartiality. ${ }^{35}$ Corrupt governmental behavior means benefits the corrupt and at a cost to everyone else. When the police are corrupt, public trust in government erodes along with the police's loss of legitimacy. ${ }^{36}$ Consequently, perceived public-sector corruption can be assumed to have a negative impact on trust in the police. Based on these theoretical considerations, the following hypothesis can be formulated:

Hc: The higher the perceived public-sector corruptionis, the lower the level of trust in the police is.

26 Mark E. Warren, "What Does Corruption Mean in a Democracy?, "American Journal of Political Science 48, no. 2 (2004).

27 Gökhan R. Karahan, R. M. Coats, and William F. Shughart, "Corrupt Political Jurisdictions and Voter Participation," Public Choice 126, 1-2 (2006); Tatiana Kostadinova, "Abstain or Rebel: Corruption Perceptions and Voting in East European Elections," Politics \& Policy 37, no. 4 (2009).

28 Kristyna Chabova, "Corruption in European Countries: A Cross-National Comparison," in Values and identities in Europe: Evidence from the European Social Survey, ed. Michael J. Breen, Routledge advances in sociology 202 (London, New York: Routledge/Taylor \& Francis Group, 2017).

29 Ben Brown and Wm R. Benedict, "Perceptions of the Police: Past Findings, Methodological Issues, Conceptual Issues and Policy Implications," Policing: An International Journal of Police Strategies \& Management 25, no. 3 (2002). William Mishler and Richard Rose, "What Are the Origins of Political Trust? Testing Institutional and Cultural Theories in Post-communist Societies," Comparative Political Studies 34, no. 1 (2001).

31 Jens Borchert, "Einleitung: Von Berufskölnern, alten Römern und paradoxen Konsequenzen," in Politische Korruption, ed. Jens Borchert, Sigrid Leitner and Klaus Stolz (Wiesbaden: Springer, 2000).

Parikshit K. Basu, "Corruption: A Theoretical Perspective and Relevance for Economic Growth," International Review of Business Research Papers 2, no. 4 (2006). Kääriäinen, "Trust Police." Bo Rothstein, Social Traps and the Problem of Trust (Cambridge University Press, 2005). Eric M. Uslaner, "Trust and Corruption," in The New Institutional Economics of Corruption, ed. Johann G. Lambsdorff, Markus Taube and Matthias Schramm, Routhledge frontiers of political economy 64 (London: Routledge, 2006). 


\section{Human Values}

Other important factors that explain trust in the police are human values. To understand individuals, groups, or institutions from a scientific point of view, the concept of value is often used to explain social phenomena. Human values on the individual level express abstract beliefs about desirable goals, ordered by relative importance, that guide individuals as they evaluate events, people, and actions. ${ }^{37}$ Schwartz analyzed the different value structure of individuals within cultures and providedatheoretical foundation. The Schwartz Value Theory is used instead of Inglehart Theory, ${ }^{38}$ mainly because of the availability of the data in the ESS and its better-drawn distinctionsamong values and attitudes. ${ }^{39}$

Schwartz human value theory says that human values form a motivational continuum and that the importance of each value varies between individuals. That means that each individual hierarchically orders his or her values. This hierarchical ordering of values is relatively stable across time and situations. ${ }^{40}$ In contrast, attitudes are less ordered hierarchically and less stable across time and situations. Each value has consequences, and these consequences may be compatible or in conflict with other values. $^{41}$

The model in Figure 1 shows the relations between the 10 first-order values in the motivational continuum, as well as the four second-order values. Values next to each other are more similar than values on the opposite side, which often conflict. ${ }^{42}$

From each of the four second orders of values, the value with a higher theoretical explanation is included for the analyses.

The police have three main duties: firstly, to provide personal protection, secondly, to promotesocial order, and thirdly, to prevent actions that could violate rules, social norms, or citizen's rights. ${ }^{43}$ These duties are the basic motivations behind the three

Milton Rokeach, The Nature of Human Values (New York, London: The Free Press; Collier MacMillan, 1973); Shalom H. Schwartz, "Universals in the Content and Structure of Values:

Theoretical Advances and Empirical Tests in 20 Countries," in Advances in experimental social psychology, vol. 25, ed. Mark P. Zanna, Advances in Experimental Social Psychology (San

Diego: Academic Press, 1992), 25.

38 Ronald Inglehart, Modernization and Postmodernization: Cultural, Economic, and Political Change in 43 Societies (Princeton: Princeton University Press, 1997).

Eldad Davidov et al., "Individual Values, Cultural Embeddedness, and Anti-Immigration Sentiments: Explaining Differences in the Effect of Values on Attitudes Toward Immigration Across Europe," Kölner Zeitschriftfür Soziologie und Sozialpsychologie 66, S 1 (2014).

40 Schwartz, "Universals Structure of Values," 25.

41 Schwartz, "Universal Aspects of Human Values."

42 Schwartz, "Universal Aspects of Human Values."

43 Sylvia M. Wilz, "Die Polizei als Organisation," in Handbuch Organisationstypen, ed. Maja Apelt and Veronika Tacke (Wiesbaden: VS Verlag für Sozialwissenschaften, 2012). 


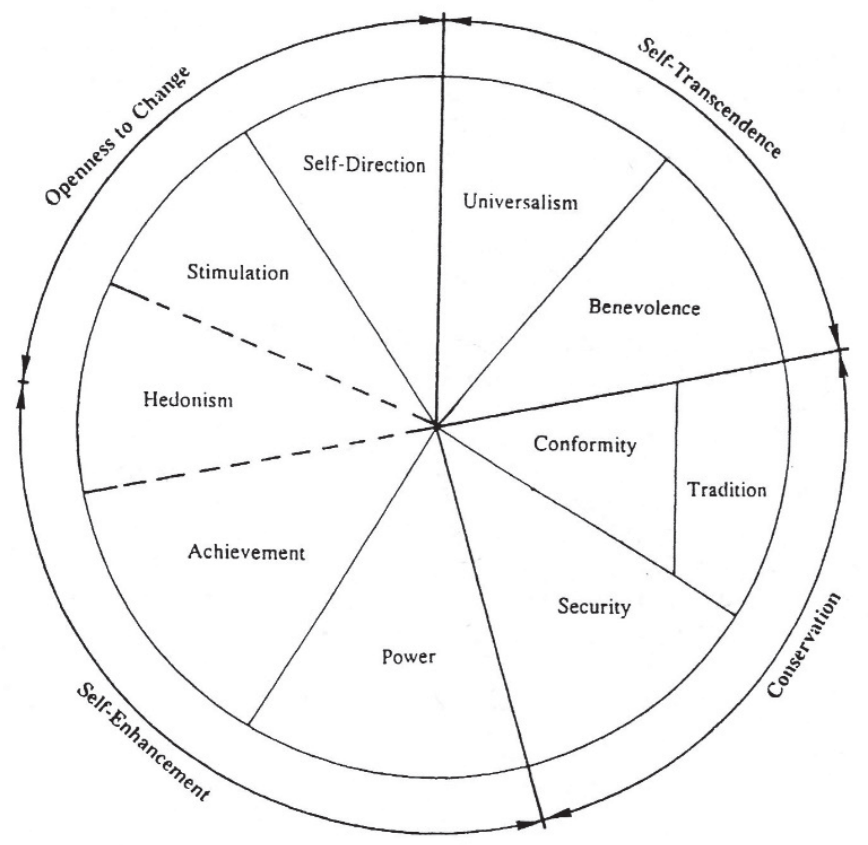

Figure 1: Theoretical model of relations among ten motivational types of

value and the four second-order values based on Schwartz

first-order values security, tradition, and conformity. ${ }^{44}$ Studies show that these three first-order values are often not discriminatory, ${ }^{45}$ so the value of conservation, which is a second-order value, is used. The hypothesis is accordingly:

$\mathrm{Hi}_{1}$ : The more important the value of conservation is, the higher the level of trust in the police is.

The downside of the basic functions of the police in particular is that they restrict the scope for action and limit individual freedom. ${ }^{46}$ However, it is precisely this autonomy that is the basic motivation for the value of self-direction, which is why the assumption is that the police block this value. This leads to the following hypothesis:

$\mathrm{Hi}_{2}$ : The more important the value of power is, the higher the level of trust in the police is.

44 Schwartz, "Universals Structure of Values," 25.

45 Eldad Davidov, "Testing for comparability of human values across countries and time with the third round of the European Social Survey," International Journal of Comparative Sociology 51, no. 3 (2010). 
The police hold a position of power in society. ${ }^{47}$ There is a homosociality between people for whom dominance over people and resources is important and the police, who have this authority to enforce the law. Homosociality reduces complexity and thus increases trust. ${ }^{48}$ From this, the following hypothesis can be formulated:

$\mathrm{Hi}_{3}$ : The more important the value of self-direction is, the lower the level of trust in the police is.

As a government institution, the police must treat all people fairly and equally. ${ }^{49}$ This is also the basic motivation behind the universalism value. Therefore, people for whom the universalism value is important will trust the police more because the police protect the welfare of all fairly and equally, thereby satisfying that value. The universalism value is preferred to the benevolence value for analysis since it is more important to examine equality for all, which is assumed by the police, than to capture the emphasis on close relationships, which is covered by the benevolence value. The hypothesis is accordingly:

$\mathrm{Hi}_{4}$ : The more important the value of universalism is, the higher the level of trust in the police is.

\section{Data and measurement}

\section{Data}

The individual-level empirical data come from the eighth wave (2016) of the ESS.50 Twenty-three countries were included in the analyses. People aged 15 and older living in a private household are the sample; there are44,17orespondents in total. The following 23 countries, with their abbreviation and effective sample size in parentheses, were included in the analyses: Austria (AT; 2004), Belgium (BE; 1750), Czechia (CZ; 2269), Estonia (EE; 2018), Finland (FI; 1921), France (FR; 2068), Germany (DE; 2834), Hungary (HU; 16o9), Iceland (IS; 871), Ireland (IE; 2745), Israel (IL; 2547), Italy (IT; 2599), Lithuania (LI; 2118), Netherlands (NL; 1675), Norway (NO; 1539), Poland (PO; 1689),

47 Wilz, "Polizei."

48 Luhmann, Vertrauen.

49 Tom R. Tyler, "Public Trust and Confidence in Legal Authorities: What do Majority and Minority Group Members want from the Law and Legal Institutions?," Behavioral sciences \& the law 19, no. 2 (2001); Jason Sunshine and Tom R. Tyler, "The Role of Procedural Justice and Legitimacy in Shaping Public Support for Policing," Law \& Society Review 37, no. 3 (2003). 
Portugal (PT; 1259), Russian Federation (RU; 2430), Slovenia (SI; 13O3), Spain (ES; 1955), Sweden (SE; 1541), Switzerland (CH; 1517), and United Kingdom (UK; 1909).

The country-level empirical data come from the Transparency International's CPI 2015. The CPI ranks countries by the perceived corruption that exists among public officials and politicians. The index collects its data from different sources, including adata composite from country experts, business analysts, and public pools. ${ }^{51}$ The CPI has a value from theoretical o to 100 . Zero means the perceived corruption is the highest, while 100 stands for the lowest perceived corruption.

\section{Variables}

Trust in the police. This variable is the dependent variable in the model. Respondents were asked the following question: 'Using this card, please tell me on a score of o-10 how much you personally trust each of the institutions I read out. Zero means you do not trust an institution at all, and 10 means you have complete trust: The police?'

Values. The ESS includes a shortened version of the Portrait Values Questionnaire. ${ }^{52}$ Each value is measured with two items (with one exception: universalism is measured with three items). Respondents answered the following question: 'Now I will briefly describe some people. Please listen to each description and tell me how much each person is or is not like you. The responses are on a six-point rating scale ranging from 'very much like me' (1) to 'not like me at all' (6). The scores of the items were reversed so that higher scores indicate greater value of importance.

Controlvariables. Variables that had an influence on trust in the police in previous studies, as well as their availability, resulted in the selection of control variables used. Previous research show that older people have more trust in the police than younger people. ${ }^{53} \mathrm{Age}$ is grouped into five categories ( 15 to 17,18 to 29,30 to 45,46 to 6 o (reference category), and 61 and older). A higher educated person has a higher trust in the police. ${ }^{54}$ The level of education was measured by taking the highest achieved level of education (low, middle, high). Middle education level is the reference category. Gender was used as a control variable (man as a reference). The majority of studies find that women have more trust in the police than men..$^{55}$ Generalized trust is an additional

$5^{1} \quad$ For further detailed information: https://www.transparency.org/cpi2015.

$5^{2}$ Shalom H. Schwartz, "Value orientations: Measurement, antecedents and consequences across nations," Measuring attitudes cross-nationally: Lessons from the European Social Survey, 2007.

Abel O. Afon and Adewumi I. Badiora, "Accounting for variation in perception of police: A study of residents in a Nigerian city," The Police Journal 89, no. 3 (2016); Liqun Cao, James Frank, and Francis T. Cullen, "Race, community context and confidence in the police," American Journal of Police 15, no. 1 (1996); Liqun Cao, Steven J. Stack, and Yi Sun, "Public attitudes toward the police," Journal of Criminal Justice 26, no. 4 (1998)

Afon and Badiora, “Accounting” Christopher J. Anderson and Matthew M. Singer, "The Sensitive Left and the Impervious Right," Comparative Political Studies 41, 4-5 (2008). 
control variable. A higher generalized trust leads to higher trust in institutions. ${ }^{56} \mathrm{~A}$ migration background exists if at least one of the parents was not born in that country (no migration background is the reference category). In general, having migrated leads to a lower level of trust in the police. ${ }^{57} \mathrm{~A}$ person with right-wing political orientation has a higher trust level. ${ }^{8}$ For the political orientation, a three-classed scale (left, middle (reference category), right) is used.

\section{Modeling strategy}

To analyze individual and contextual factors in the same model, two-level multilevel models are used to explore differing levels of trust in police forces. In this case individuals are nested within countries. It is possible to use a multilevel analysis, although the number of cases on the second level is low with 23 countries. However, distortions of the standard error are possible. ${ }^{99}$ The calculated models increase in complexity; this strategy is proposed by Hox (2002). To do so the ML win program was used. ${ }^{60}$ The first model is a so-called empty model, and it only includes the intercept. The second model includes the four human values, followed by the control variables. The third model includes the context variable CPI. Descriptive statistics are calculated with missing values, while bi- und multivariate statistics handle the missing data by using multiple imputation. ${ }^{61}$ For the imputation the package HMISC ${ }^{62}$ in the statistic program R was used. ${ }^{63}$ All variables were standardized.

L. Gabbidon and George E. Higgins, "The Role of Race/Ethnicity and Race Relations on Public Opinion Related to the Treatment of Blacks by the Police," Police Quarterly 12, no. 1 (2009).

56 Kimmo Grönlund and Maija Setälä, "In Honest Officials We Trust: Institutional Confidence in Europe," The American Review of Public Administration 42, no. 5 (2011).

57 Stan L. Albrecht and Miles Green, "Attitudes toward the police and the larger attitude complex: Implications for Police-Community Relationships," Criminology 15, no. 1 (1977); Jonathan Jackson et al., "Why do People Comply with the Law? Legitimacy and the Influence of Legal Institutions," British Journal of Criminology 52, no. 6 (2012); Olga Semukhina and K. M. Reynolds, “Russian citizens' perceptions of corruption and trust of the police," Policing and Society 24, no. 2 (2014).

$5^{8}$ Paul R. Benson, "Political Alienation and Public Satisfaction with Police Services," The Pacific Sociological Review 24, no. 1 (1981).

59 Daniel Stegmueller, "How Many Countries for Multilevel Modeling? A Comparison of Frequentist and Bayesian Approaches," American Journal of Political Science 57, no. 3 (2013).

6o Christopher Charlton et al., MLwiN (Bristol: Centre for Multilevel Modelling, 2017).

$61 \quad$ Simon Grund, Oliver Lüdtke, and Alexander Robitzsch, "Multiple Imputation of Missing Data for Multilevel Models: Simulations and Recommendations," Organizational Research Methods 21, no. 1 (2018).

62 Frank E. Harrell, Hmisc: Harrell Miscellaneous. R package (2019).

63 R Core Team, R: A language and environment for statistical (Wien, Österreich: R Foundation for Statistical Computin, 2019), https://www.R-project.org/. 
Causality analyses can only be generated with experiments ${ }^{64}$ and/or panel data. ${ }^{65}$ Nevertheless, in this paper, the CPI is used upstream to take into account the temporal aspect to generate a clear temporal sequence and thus treat the perceived corruption as a cause for trust in the police.

Individual values are among the most abstract types of cognition, ${ }^{66}$ and the more abstract a cognition, the more resistant it is to change. ${ }^{67}$ It can be assumed that values influence the attitudes of individuals. Values are therefore upstream of attitudes. ${ }^{68}$

\section{Results}

\section{Descriptive overview}

In Figure 2 trust in the police in European countries is presented. The scale is an 11-pointscale (o means 'no trust at all,'10 means 'complete trust'). Trust in the police in the European countries vary, and it is high especially in Scandinavia, being thehighest in Finland (8.22), followed by Iceland (7.84), and Norway (7.44). Only in Switzerland (7.23), Austria (7.04), and Germany (7.01) does the level of trust in the police also lie between 7 and 8.

On the other side of the range Russia, has the lowest level of trust in the police (4.43), followed by Israel (5.13), Poland (5.74) and Czech Republic (5.78). Russia and Israel have $11 \%$ and $10 \%$, respectively, of answers in the lowest category: 'no trust at all'. The average of all 23 countries lies around 6.47.

The CPI 2015 displays the varieties of the perceived public-sector corruption in the European countries in Figure 3. On this o-10o scale, a higher score means that the perceived public-sector corruptionis lower, while the lower values mean that the perceived public-sector corruptionin the respective country is higher.

The following picture shows the rating of the CPI 2015 for the relevant countries for this paper. Finland leads this ranking with a score of 9o, followed by Sweden (CPI: 89), Norway (CPI: 88), Switzerland (CPI: 86), the Netherlands (CPI: 84), as well as Germany and United Kingdom (each CPI: 81). The lowest score lies with 29 in Russia, followed by Italy (CPI: 44), and Hungary (CPI: 51).

64 Kosuke Imai et al., "Unpacking the Black Box of Causality: Learning about Causal Mechanisms from Experimental and Observational Studies," American Political Science Review 105, no. 4 (2011).

65 David R. Heise, “Causal Inference from Panel Data," Sociological Methodology 2 (1970).

66 Schwartz, "Universals Structure of Values," 25.

67 Anat Bardi et al., "Value stability and change during self-chosen life transitions: Self-selection versus socialization effects," Journal of Personality and Social Psychology 106, no. 1 (2014).

68 Pamela M. Homer and Lynn R. Kahle, "A structural equation test of the value-attitude-behavior hierarchy," Journal of Personality and Social Psychology 54, no. 4 (1988). 


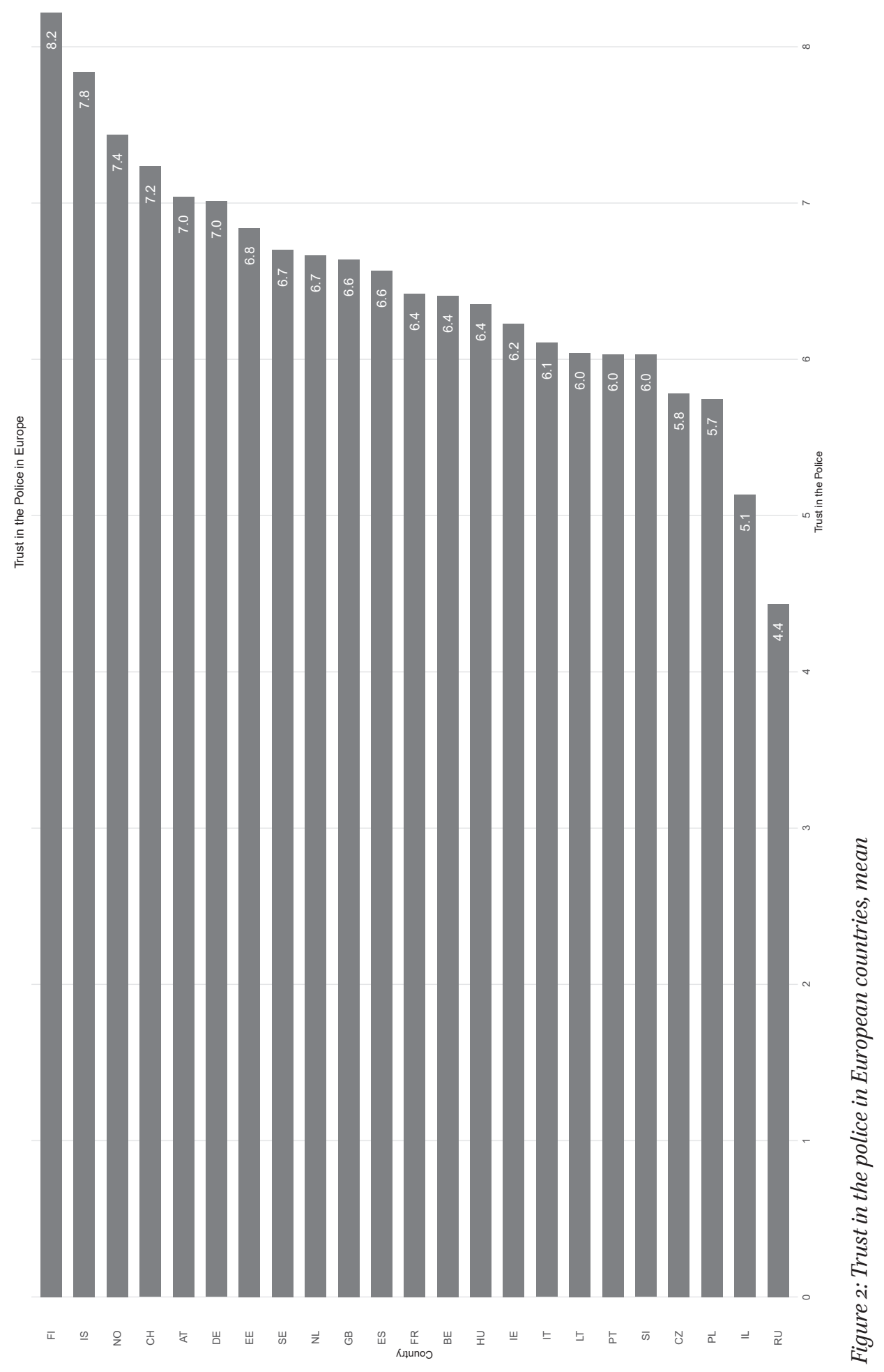




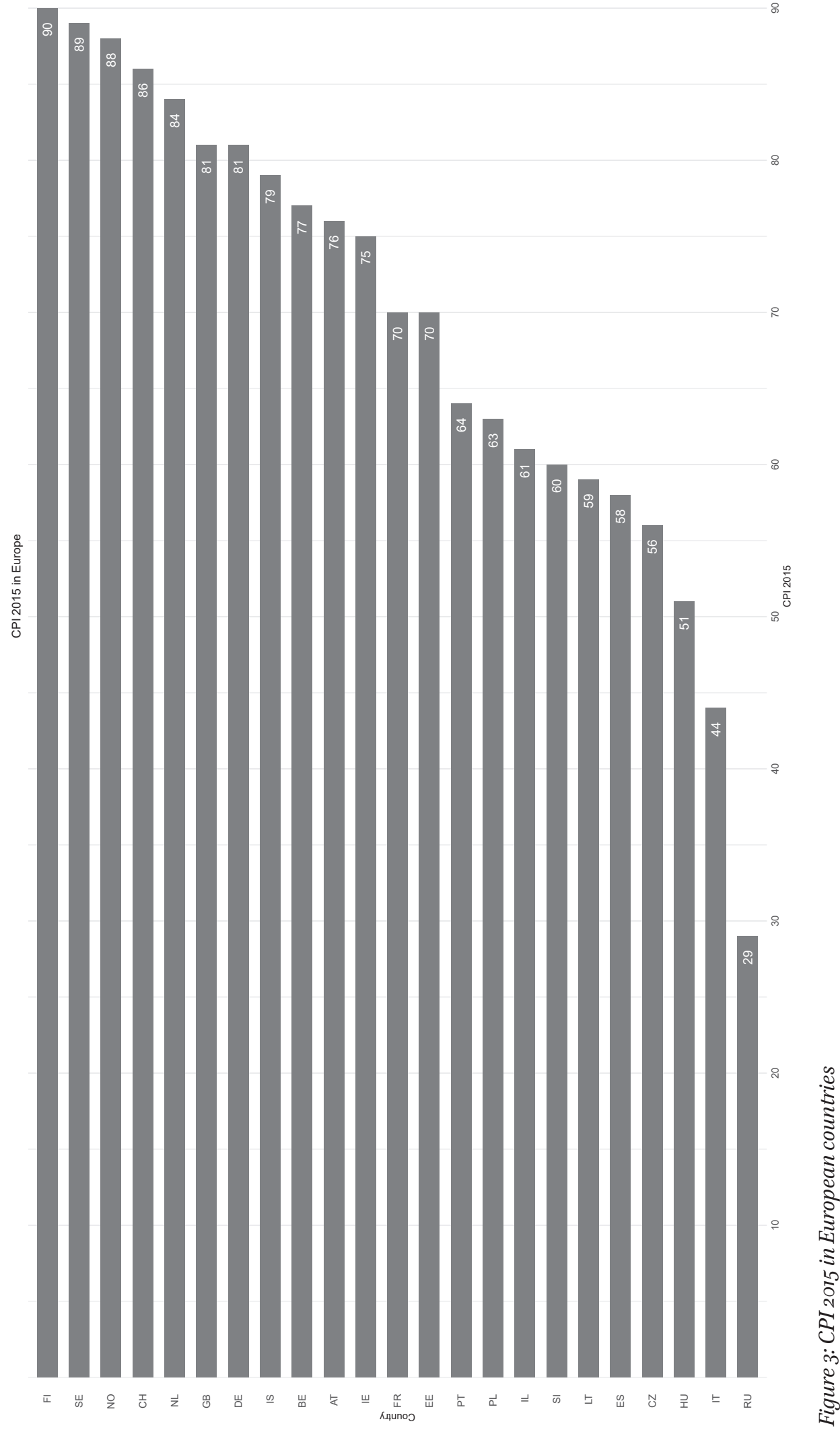




\section{Human Values}

In the following Figure 4, the mean scores of all human values of each country is presented. In this 1-6 scale, a higher score means the value is more important. While the value conservation in Sweden with 3.9 is on the lower end of the scale, in Poland and Slovenia the value conservation is on the other end of the scale with a mean of 4.7. The importance of the power value is more diverse within European countries. In France the power value is the most unimportant (2.6) and in Hungary (4.0) the most important. The power value for each country is the most unimportant one. The self-direction and universalism values are more important in European countries than conservation and power. The range for the self-direction valueextendsfrom 4.1 (LI) to 5.0 (CH) and the universalism value has a range from 4.3 (LI, CY) to 5.1 (ES).

\section{Correlations}

The highest two correlations are between the universalism and conservation values (o.40), followed by the correlation of the universalism and self-direction values (0.39). The correlation in between generalized trust and the trust in the police is with 0.27 moderate. ${ }^{69}$

The correlation between trust in the police on the aggregated country level and the CPI 2015 is 0.79 . These results must be treated with due caution because of the low case number of 23 countries. In general, in countries with a lowerlevel ofperceived public-sector corruptionthe level of trust in the police is higher. In countries with a higher perceived public-sector corruption the level of trust in the police is lower.

\section{Multilevel analysis}

This section describes the results of the multilevel analysis. For the analysis, the model is stepwise expanded with groups of variables. The results are shown in Table 1.

Model o contains only the intercepts. It shows that differences lie on the microlevel as well as on the macro-level. This means that both kind of factors are necessary to explain individual differences and differences between countries in their trust in the police. Both variances are significant and the Intra Class Correlation (ICC) is o.111. Eleven percent of the variance is found on the country level, while $89 \%$ of the variance is on the individual level.

Model 1 includes the human values to explain trust in the police. The conservation and universalism values have a positive, significant effect on the level of trust, while the self-direction value has a negative, significant effect. Power has no effect on the level of trust in the police. In this model, the conservation value has the strongest effect on the level of trust in the police. This meansthat peoplefor whom the conservation value is

69 The correlation matrix is in the Appendix A. 
on Trust in the Police: A European Cross-National Perspective

TABLE 1: MULTILEVEL MODELS EXPLAINING TRUST IN THE POLICE IN EUROPEAN COUNTRIES.

\begin{tabular}{|c|c|c|c|c|c|c|c|c|}
\hline & \multicolumn{2}{|c|}{ Model 0} & \multicolumn{2}{|c|}{ Model 1} & \multicolumn{2}{|c|}{ Model 2} & \multicolumn{2}{|c|}{ Model 3} \\
\hline & Coef & SE & Coef & SE & Coef & SE & Coef & SE \\
\hline \multicolumn{9}{|l|}{ Fixed Effects } \\
\hline Intercept & .033 & .070 & .034 & .072 & .033 & .064 & .015 & .04 \\
\hline \multicolumn{9}{|l|}{ Human Values } \\
\hline Conservation & & & $.075^{* * *}$ & .005 & $.101 * * *$ & .005 & $.101 * * *$ & .00 \\
\hline Power & & & -.005 & .005 & -.006 & .005 & -.006 & .00 \\
\hline Self-Direction & & & $-.043^{* * *}$ & .005 & $-.048^{* * *}$ & .005 & $-.048^{* * *}$ & .00 \\
\hline Universalism & & & $.038 * * *$ & .005 & $.015^{* *}$ & .005 & $.015^{* *}$ & .00 \\
\hline \multicolumn{9}{|l|}{ Control Variable } \\
\hline \multicolumn{9}{|l|}{ Age grouped (RC: 46-60) } \\
\hline $15-17$ & & & & & $.061 * * *$ & .005 & $.061 * * *$ & .00 \\
\hline $18-30$ & & & & & $.017^{* *}$ & .005 & $.017^{* *}$ & .00 \\
\hline $31-45$ & & & & & .007 & .005 & .007 & .00 \\
\hline $61+$ & & & & & $.034^{* * *}$ & .005 & $.034 * * *$ & .00 \\
\hline \multicolumn{9}{|l|}{ Level of Education (RC: middle) } \\
\hline low & & & & & $-.020 * * *$ & .005 & $-.020 * * *$ & .00 \\
\hline high & & & & & $.038 * * *$ & .005 & $.038 * * *$ & .00 \\
\hline Generalized Trust & & & & & $.219 * * *$ & .005 & $.219 * * *$ & .00 \\
\hline Gender (RC: man) & & & & & $.027^{* * *}$ & .004 & $.028 * * *$ & .00 \\
\hline Migrationsbackground (RC: no & & & & & $.023 * * *$ & .005 & $.023 * * *$ & .00 \\
\hline \multicolumn{9}{|l|}{ Political Orientation (RC: middle) } \\
\hline left & & & & & $-.024 * * *$ & .005 & $-.024 * * *$ & .00 \\
\hline right & & & & & $.029 * * *$ & .005 & $.029 * * *$ & .00 \\
\hline \multicolumn{9}{|l|}{ Macro Variable } \\
\hline Lower Perceived Corruption & & & & & & & $.237^{* * *}$ & .04 \\
\hline \multicolumn{9}{|l|}{ Random effects } \\
\hline Residual Variance $\left(\mathrm{e}_{0}\right)$ & $.886^{* * *}$ & .006 & $.878^{* * *}$ & .006 & $.825^{* * *}$ & .006 & $.825^{* * *}$ & .00 \\
\hline Random Intercept $\left(\mathrm{u}_{0}\right)$ & $.111^{* * *}$ & .033 & $.117^{* * *}$ & .035 & $.093^{* * *}$ & .028 & $.041^{* * *}$ & .01 \\
\hline intra class correlation (ICC) & .111 & & .118 & & .101 & & .047 & \\
\hline \multicolumn{9}{|l|}{ Explained Variance } \\
\hline $\begin{array}{l}\% \text { reduction of the residual } \\
\text { variance }\end{array}$ & & & $0.9 \%$ & & $6.9 \%$ & & $6.9 \%$ & \\
\hline $\begin{array}{l}\% \text { reduction of the random } \\
\text { intercept }\end{array}$ & & & $-5.4 \%$ & & $16.2 \%$ & & $63.1 \%$ & \\
\hline $\begin{array}{l}\mathrm{Ni}=44170 ; \mathrm{Nj}=23 \\
\text { Multiple imputation was used to } \\
\mathrm{RC}=\text { reference category; Coef } \\
\text { Source: ESS8 } 2016-2018, \mathrm{CPI} \\
\text { Significances: }{ }^{*} 0.01<p<0.05\end{array}$ & $\begin{array}{l}\text { handle mi } \\
=\text { Coefficie } \\
2015 ; \text { own } \\
{ }^{* *} 0.001<\end{array}$ & $\begin{array}{l}\text { ing val } \\
\text {; SE } \\
\text { alculat }\end{array}$ & $\begin{array}{l}\text { All Effects } \\
\text { andard erro } \\
{ }^{* *} p<0.001\end{array}$ & sta & dized. & & & \\
\hline
\end{tabular}


important have more trust in the police. In contrast, people forwhom the self-direction value is important have a lower level of trust in the police.

Model 2 is an expanded version of Model 1. In Model 2 control variables are included, specifically age, education level, generalized trust, gender, migration background, and political orientation. Taking these control variables into account, the universalism value is losing its power of explanation. The conservation and selfdirection valuesremain stable. Both the youngest people, those 15 to17 years old, and the next youngest people, those 18 to 3 o years old, have more trust in the police than the people in the reference age group, those 46 to 60 years old. Those who are $3^{1}$ to 45 years old do not significantly differ from the reference category. The oldest people in the sample, those 61 years old and older, also have higher trust in the police when compared to thosein the 46 to 6 o years-old-age group. The level of education plays a role in explaining trust in the police. People with a lower education have less trust in the police than people with a higher level of education.

Generalized trust also is an important factor in explaining trust in the police. People who tend to trust other people in general alsotend to have higher trust in the police. This factor of generalized trust is the most important one in this model.

In terms of gender, women trust the police significantly more than men do. People who have not migrated trust the police significantly more than people who have migrated. People on the political left trust the police less than people in the political center; while people on the right trust the police more.

Model 3 takes the context variable of CPI 2015into account. The effect of this macro variable has a powerful explanatory force. A lower level of perceived publicsector corruptionleads to a higher level of trust in the police. The explained variance in this model compared to model o is reduced by about $63 \%$. When compared with model 2 the reduction is $47 \%$, this reduction gets only with one new variable in it: the macro variable perceived public-sector corruption. The ICC lies at 0.047.

The 23 countries have different aggregated levels of trust in the police. The Scandinavian countries have the highest level of trust, while Russia has the lowest.

The study shows, in an empirical way, that a high perceived public-sector corruption findinginfluences the level of trust in the police in a powerfully negative way; therefore, my hypotheses on corruption have empirical support. This result supports earlier studiesanalyzed the link between corruption and trust in state institutions. ${ }^{70}$

In addition to the perceived public-sector corruption, human values on the individuallevel explain some of the differences in trust in the police. People for whom the conservation value is important have a higher amount of trust in the police. This can be explained by a fundamental police function: to protect the security of every citizen, which, in turns, promotes stability. People who consider the universalism value as important also have greater trust in the police. On the other hand, someone who values self-direction might have less trust in the police because the police can restrict a person's independent actions and liberty. These results show that three of 
four hypotheses on the individual level $\left(\mathrm{Hi}_{1}, \mathrm{Hi}_{3}\right.$ and $\left.\mathrm{Hi}_{4}\right)$ are supported, while the hypotheses on power is not supported.

Furthermore, the control variables also influence the level of trust in the police. People under 45 years old and people older than 6 o years old trust the police more than people 45 to 6 o years old. People who have a higher trust in other people in general also have a higher level of trust in the police. A higher educated, female, who has never migrated and who identifies with the political right would trust the police the most.

\section{Discussion and Conclusion}

This study's purpose was to discover how human values as well as perceived publicsector corruption can explain the differences in citizens' trust in their police. Although perceived public-sector corruption in Europe is lower than it is globally, it nevertheless influences trust in the police and thus the legitimacy of the police as an institution. A state must first get corruption under control to increase trust in the police. In addition to this relationship at the country level, there are also explanations at the individual level. Human values have an influence on how the police are trusted. However, individual values play a subordinate role. But the police can activate different values by addressing the people differently and thus also build a stronger, more positive relationship with the population.

This paper has some theoretical and empirical limitations. From a theoretical perspective, only one main variable on the country-level is used to explain trust in the police. While the explained variance in the trust in the police among the 23 countries decreasessubstantially whenthe perceived public-sector corruptionis considered, further explanatory variables can also play a role in the variance. For example, the police differ between these 23 countries. Police forces are a national institution, they depend on the rules and legitimation oftheir country, they are structuresaccording to their history and needs, and they can differ in their rights and duties. ${ }^{71}$

Another limiting factor could be the political system in which the police forces are embedded. A post-soviet history can influence either the relationship of the people towards their police forces, as well as the comprehension of what is corrupt and what is not. ${ }^{72}$

In addition, other limiting factors can play a role on the individuallevel. Personal experiences with the police and the relative fairness of police procedures can influence the level of trust in the police. ${ }^{73}$

71 Rob I. Mawby, "Models of policing," in Handbook of Policing, ed. Tim Newburn, 2nd ed. (London: Routledge, 2009).

72 Richard Rose, William Mishler and Christian Haerpfer, Democracy and its alternatives: Understanding post-communist societies (JHU Press, 1998).

73 Silvia Staubli, Trusting the Police: Comparisons across Eastern and Western Europe (Bielefeld: transcript, 2017), http://www.oapen.org/search?identifier=634763. 
This paper also faced methodological limitations. The CPI is a composite index based on country-experts and other sources. While the CPI is a good indicator to compare countries, it is not possible to cover the heterogeneity of perceived publicsector corruptionwithin a country. Furthermore, a perception of corruption does not necessarily reveal the real level of corruption. ${ }^{74}$ Different measurements should be developed and used by further research in the topic of corruption to address corruption's clandestine nature.

More research is necessary to understand corruption, trust in the police, human values, and the connection between these social phenomena.

\section{Bibliography}

Afon, Abel O., and Adewumi I. Badiora. "Accounting for Variation in Perception of Police: A Study of Residents in a Nigerian City." The Police Journal 89, no. 3 (2016): 241-56.

Albrecht, Stan L., and Miles Green. "Attitudes toward the Police and the Larger Attitude Complex: Implications for Police-Community Relationships.” Criminology 15, no. 1 (1977): 67-86.

Anderson, Christopher J., and Matthew M. Singer. "The Sensitive Left and the Impervious Right." Comparative Political Studies 41, 4-5 (2008): 564-99.

Bardi, Anat, Kathryn E. Buchanan, Robin Goodwin, Letitia Slabu, and Mark Robinson. "Value Stability and Change during Self-Chosen Life Transitions: Self-Selection versus Socialization Effects." Journal of Personality and Social Psychology 106, no. 1 (2014): 131-47.

Basu, Parikshit K. "Corruption: A Theoretical Perspective and Relevance for Economic Growth." International Review of Business Research Papers 2, no. 4 (2006): 59-68.

Benson, Paul R. "Political Alienation and Public Satisfaction with Police Services." The Pacific Sociological Review 24, no. 1 (1981): 45-64.

Benz, Arthur. "Vertrauensbildung in Mehrebenensystemen." In Politisches Vertrauen: Soziale Grundlagen reflexiver Kooperation. Edited by Rainer Schmalz-Bruns and Reinhard Zintl, 275-91. Schriftenreihe der Sektion Politische Theorien und Ideengeschichte in der Deutschen Vereinigung für Politische Wissenschaft 2. Baden-Baden: Nomos, 2002.

Borchert, Jens. "Einleitung: Von Berufskölnern, alten Römern und paradoxen Konsequenzen." In Politische Korruption. Edited by Jens Borchert, Sigrid Leitner and Klaus Stolz, 7-17. Wiesbaden: Springer, 2000.

Brown, Ben, and Wm Reed Benedict. "Perceptions of the Police: Past Findings, Methodological Issues, Conceptual Issues and Policy Implications." Policing: An International Journal of Police Strategies \& Management 25, no. 3 (2002): 543-80.

74 Kristyna Chabova, "Measuring Corruption in Europe: Public Opinion Surveys and Composite Indices," Quality \& Quantity 51, no. 4 (2017). 
Cao, Liqun, James Frank, and Francis T. Cullen. "Race, Community Context and Confidence in the Police." American Journal of Police 15, no. 1 (1996): 3-22.

Cao, Liqun, Steven J. Stack, and Yi Sun. "Public Attitudes toward the Police." Journal of Criminal Justice 26, no. 4 (1998): 279-89.

Chabova, Kristyna. "Corruption in European Countries: A Cross-National Comparison." In Values and identities in Europe: Evidence from the European Social Survey. Ed. Michael J. Breen, 143-59. Routledge advances in sociology 202. London, New York: Routledge/Taylor \& Francis Group, 2017.

Chabova, Kristyna. "Measuring corruption in Europe: Public opinion surveys and composite indices." Quality \& Quantity 51, no. 4 (2017): 1877-1900.

Charlton, Christopher, Jon Rasbash, William J. Browne, Michael J. R. Healy, and Bruce Cameron. MLwiN. Bristol: Centre for Multilevel Modelling, 2017.

Cheurprakobkit, Sutham. "Police-Citizen Contact and Police Performance Attitutional Differences between Hispanics and Non-Hispanics." Journal of CriminalJustice 28, no. 4 (2000): $325^{-36}$.

Davidov, Eldad. "Testing for Comparability of Human Values across Countries and Time with the Third Round of the European Social Survey." International Journal of Comparative Sociology 51, no. 3 (2010): 171-91.

Davidov, Eldad, Bart Meulemann, Shalom H. Schwartz, and Peter Schmidt. "Individual Values, Cultural Embeddedness, and Anti-Immigration Sentiments: Explaining Differences in the Effect of Values on Attitudes toward Immigration across Europe." Kölner Zeitschrift für Soziologie und Sozialpsychologie 66, S 1 (2014): 263-85.

Dederichs, Andrea Maria. "Vertrauen als affektive Handlungsdimension: Ein emotionssoziologischer Bericht." In Interpersonales Vertrauen: Theorien und empirische Befunde. Edited by Martin K. W. Schweer, 62-77. Wiesbaden: VS Verlag für Sozialwissenschaften, 1997.

Easton, David. A Systems Analysis of Political Life. New York: Wiley, 1965.

Ervasti, Heikki, Antti Kouvo, and Takis Venetoklis. "Social and Institutional Trust in Times of Crisis: Greece, 2002-2011." Social Indicators Research 141, no. 3 (2019): 1207-31.

ESS. "Data Round 8: Data file edition 2.1." Norwegian Centre for Research Data, Norway, Data Archive and distributor of ESS data for ESS ERIC, Norway, 2016.

Gabbidon, Shaun L., and George E. Higgins. "The Role of Race/Ethnicity and Race Relations on Public Opinion Related to the Treatment of Blacks by the Police." Police Quarterly 12, no. 1 (2009): 102-15.

Gamson, William A. Power and discontent. Homewood Ill.: Dorsey Press, 1968.

Grönlund, Kimmo, and Maija Setälä. "In Honest Officials We Trust: Institutional Confidence in Europe." The American Review of Public Administration 42, no. 5 (2011): 523-42.

Grund, Simon, Oliver Lüdtke, and Alexander Robitzsch. "Multiple Imputation of Missing Data for Multilevel Models: Simulations and Recommendations." Organizational Research Methods 21, no. 1 (2018): 111-49. 
Gukenbiehl, Hermann L. "Institution und Organisation." In Einführung in Hauptbegriffe der Soziologie. Edited by Hermann Korte and Bernhard Schäfers. 6th ed., 143-59. Wiesbaden: VS Verlag für Sozialwissenschaften, 2003.

Harrell, Frank E. Hmisc: Harrell Miscellaneous. R package. 2019.

Heise, David R. "Causal Inference from Panel Data." Sociological Methodology 2 (1970): 3. Höhne, Benjamin. Vertrauen oder Misstrauen? Wie stehen die Ostdeutschen 15 Jahre nach der Wiedervereinigung zu ihrem politischen System? Marburg: Tectum, 2006. http:// deposit.dnb.de/cgi-bin/dokserv?id=2774541\&prov=M\&dok_var=1\&dok_ext=htm.

Homer, Pamela M., and Lynn R. Kahle. "A Structural Equation Test of the Value-AttitudeBehavior Hierarchy." Journal of Personality and Social Psychology 54, no. 4 (1988): 638-46.

Hox, Joop. Multilevel Analysis: Techniques and Applications. Mahwah: Erlbaum, 2002. http://www.loc.gov/catdir/enhancements/fyo634/200105776o-d.html.

Huntington, Samuel P. "Political Development and Political Decay." World Politics 17, no. 3 (1965): 386-430.

Imai, Kosuke, Luke Keele, Dustin Tingley, and Teppei Yamamoto. "Unpacking the Black Box of Causality: Learning about Causal Mechanisms from Experimental and Observational Studies." American Political Science Review 105, no. 4 (2011): 765-89.

Inglehart, Ronald. Modernization and Postmodernization: Cultural, Economic, and Political Change in 43 Societies. Princeton: Princeton University Press, 1997.

Jackson, Jonathan, Ben Bradford, Mike Hough, Andy Myhill, Paul Quinton, and Tom R. Tyler. "Why do People Comply with the Law? Legitimacy and the Influence of Legal Institutions." British Journal of Criminology 52, no. 6 (2012): 1051-71.

Kääriäinen, Juha. "Trust in the Police in 16 European Countries: A Multilevel Analysis." European Journal of Criminology 4, no. 4 (2007): 409-35.

Karahan, Gökhan R., R. Morris Coats, and William F. Shughart. "Corrupt political jurisdictions and voter participation." Public Choice 126, 1-2 (2006): 87-106.

Kostadinova, Tatiana. "Abstain or Rebel: Corruption Perceptions and Voting in East European Elections." Politics \& Policy 37, no. 4 (2009): 691-714.

Luhmann, Niklas. Vertrauen: Ein Mechanismus der Reduktion sozialer Komplexität. 4. th ed. UTB 2185. Stuttgart: Lucius \& Lucius, 2000 [1968].

Mawby, Rob I. "Models of policing." In Handbook of Policing. Edited by Tim Newburn. 2nd ed., 17-46. London: Routledge, 2009.

Mishler, William, and Richard Rose. "What Are the Origins of Political Trust? Testing Institutional and Cultural Theories in Post-Communist Societies." Comparative Political Studies 34, no. 1 (2001): 30-62.

Morselli, Davide, Dario Spini, and Thierry Devos. "Trust in Institutions and Human Values in the European Context: A Comparison between the World Value Survey and the European Social Survey." Psicologia sociale 10, no. 3 (2015).

Newton, Kenneth, and Pippa Norris. "Confidence in Public Institutions: Faith, Culture or Performance?” In Disaffected Democracies: What's Troubling the Trilateral Countries? Ed. Susan J. Pharr and Robert D. Putnam, 52-73. Princeton, NJ: Princeton University Press, 2000. 
Nuissl, Henning. "Bausteine des Vertrauens: Eine Begriffsanalyse." Berliner Journal für Soziologie 12, no. 1 (2002): 87-108.

Obermaier, Frederik, and Bastian Obermayer. "A Storm is Coming: Panama papers." Accessed October 31, 2019. https://panamapapers.sueddeutsche.de/ articles/56fecocdarbb8d3c3495adfc/.

Obermaier, Frederik, and Bastian Obermayer. "Die Panama Papers in aller Welt: Russland." Accessed October 31, 2019. https://panamapapers.sueddeutsche.de/ articles/56fecocdarbb8d3c3495adfc/.

Pfister, Sabrina. "Vertrauen in die Polizei: Schweiz - Europa - Welt." Dissertation, Universität Zürich, 2020-forthcoming.

Plumpe, Werner. "Korruption: Annäherungen an ein historisches und gesellschaftliches Phänomen." In Geld - Geschenke - Politik: Korruption im neuzeitlichen Europa. Edited by Jens I. Engels, Andreas Fahrmeir and Alexander Nützenadel, 19-48. Historische Zeitschrift Beihefte N. F., 48. München: Oldenbourg, 2009.

Quentin, Ariès. "EU vows to act quickly on Panama Papers." Accessed October 31, 2019. https://en.wikipedia.org/wiki/Panama_Papers_(Europe).

R Core Team. R: A Language and Environment for Statistical. Wien, Österreich: $\mathrm{R}$ Foundation for Statistical Computin, 2019. https://www.R-project.org/.

Rokeach, Milton. The Nature of Human Values. New York, London: The Free Press; Collier MacMillan, 1973.

Rose, Richard, William Mishler, and Christian Haerpfer. Democracy and its Alternatives: Understanding Post-Communist Societies. JHU Press, 1998.

Rothstein, Bo. Social Traps and the Problem of Trust. Cambridge University Press, 2005. Rothstein, Bo. "Anti-Corruption: The Indirect 'Big Bang' Approach.” Review of International Political Economy 18, no. 2 (2011): 228-50.

Schwartz, Shalom H. "Universals in the Content and Structure of Values: Theoretical Advances and Empirical Tests in 20 Countries." In Advances in Experimental Social Psychology. Vol. 25. Ed. Mark P. Zanna, 1-65. Advances in Experimental Social Psychology. San Diego: Academic Press, 1992.

Schwartz, Shalom H. "Are There Universal Aspects in the Structure and Contents of Human Values?" Journal of Social Issues 50, no. 4 (1994): 19-45.

Schwartz, Shalom H. "Value Orientations: Measurement, Antecedents and Consequences across Nations." Measuring Attitudes Cross-Nationally: Lessons from the European Social Survey, 2007, 161-93.

Semukhina, Olga, and K. Michael Reynolds. "Russian Citizens' Perceptions of Corruption and Trust of the Police." Policing and Society 24, no. 2 (2014): 158-88.

Staubli, Silvia. Trusting the Police: Comparisons across Eastern and Western Europe. Bielefeld: transcript, 2017. http://www.oapen.org/search?identifier=634763.

Stegmueller, Daniel. "How Many Countries for Multilevel Modeling? A Comparison of Frequentist and Bayesian Approaches." American Journal of Political Science 57, no. 3 (2013): 748-61. 
Sunshine, Jason, and Tom R. Tyler. "The Role of Procedural Justice and Legitimacy in Shaping Public Support for Policing." Law \& Society Review 37, no. 3 (2003):513-48. The International Consortium of Investigate Journalists. "Giant Leak of Offshore Financial Records Exposes Global Array of Crime and Corruption." Accessed October 31, 2019. https://www.webcitation.org/6gVXG3LvI?url=https://www. occrp.org/en/panamapapers/overview/intro/.

Transparency International. "What is Corruption?" Accessed June 19, 2018. https://www. transparency.org/\%2owhat-is-corruption\#define.

Transparency International Schweiz. "Geschäftsgrundsätze für die Bekämpfung von Korruption, Ausgabe für kleine und mittlere Unternehmen (KMU).” Bern, 2008.

Tyler, Tom R. "Public trust and confidence in legal authorities: What do majority and minority group members want from the law and legal institutions?" Behavioral sciences \& the law 19, no. 2 (2001): 215-35.

Tyler, Tom R. "Trust and Legitimacy: Policing in the USA and Europe." European Journal of Criminology 8, no. 4 (2011): 254-66.

Uslaner, Eric M. “Trust and Corruption." In The New Institutional Economics of Corruption. Edited by Johann G. Lambsdorff, Markus Taube and Matthias Schramm, 76-92. Routhledge frontiers of political economy 64. London: Routledge, 2006.

von Alemann, Ulrich. "Politische Korruption: Ein Wegweiser zum Stand der Forschung." In Dimension politischer Korruption: Beiträge zum Stand der internationalen Forschung. Edited by Ulrich von Alemann, 13-48. Politische Vierteljahresschrift Sonderhefte. Wiesbaden: VS Verlag für Sozialwissenschaften, 2005.

Warren, Mark E. "What Does Corruption Mean in a Democracy?" American Journal of Political Science 48, no. 2 (2004): 328-43.

Wilz, Sylvia M. "Die Polizei als Organisation." In Handbuch Organisationstypen. Edited by Maja Apelt and Veronika Tacke, 113-31. Wiesbaden: VS Verlag für Sozialwissenschaften, 2012.

Sabrina Pfister is a sociologist and senior project leader at the LINK institution. She is a $\mathrm{PhD}$ candidate at the Institute of Sociology of University of Zurich, Switzerland. The aim of her dissertation is to gain a better understanding of the different trust relationships in Switzerland, Europe and the world. The influence of corruption at the country level is complemented by individual explanatory variables, mainly human values and migration background. For the analyses mainly structural equation models and multi-level analyses are used. Furthermore, her research focuses on issues such as trust in institutions, corruption and female leadership. 